\title{
Pengaruh Therapeutic Exercise Walking terhadap Sirkulasi Darah Perifer pada Pasien Diabetes Melitus Tipe 2 di Kelurahan Gebang Kecamatan Patrang Kabupaten Jember. (The Effect of Therapeutic Exercise Walking on Pheripheral Blood Circulation in Patients with Type 2 Diabetes Mellitus at Gebang Village of Patrang Sub-District Jember Regency)
}

\author{
Erti Ikhtiarini Dewi, Amadea Yollanda, Nur Widayati, Rondhianto \\ Program Studi Ilmu Keperawatan Universitas Jember \\ Jl. Kalimantan No. Kampus Tegal Boto Jember 37 Telp./Fax. (0331) 323450 \\ e-mail: rondhianto@unej.ac.id
}

\begin{abstract}
Pathological change experienced by patients with type 2 diabetes mellitus is impaired peripheral blood circulation, especially in the lower limbs and feet. Peripheral blood circulation can be examined by measuring Ankle Brachial Index (ABI). Therapeutic exercise walking is one of physical activities which can improve blood circulation. This research goal was to analyze the effect of therapeutic exercise walking on peripheral blood circulation in patients with type 2 diabetes mellitus. The research design was randomized control group pretest-posttest design. The sample size was 15 respondents as control group and 15 respondents as treatment group. Data was analyzed by using dependent t-test and independent $t$-test with significant level of 0.05. This result showed a significant increase of $A B I$ after therapeutic exercise walking in the treatment group $(p=0.001)$. However there was a significant decrease of $A B I$ between pretest and posttest in control group ( $p=0.010)$. Independent $t$-test indicated a significant difference of $A B I$ between treatment group and control group $(p=0.000)$. So, it can be concluded that there is an influence of therapeutic exercise walking on the peripheral blood circulation in patients with type 2 diabetes mellitus. Nurses should apply therapeutic exercise walking to improve peripheral blood circulation in patients with type 2 diabetes mellitus.
\end{abstract}

Keywords: type 2 diabetes mellitus, therapeutic exercise walking, ankle brachial index

\begin{abstract}
Abstrak
Perubahan patologis yang terjadi pada pasien DM Tipe 2 adalah gangguan sirkulasi darah perifer, khususnya pada anggota tubuh bagian bawah dan kaki. Sirkulasi darah perifer dapat diukur dengan Ankle Brachial Index (ABI). Therapeutic exercise walking adalah salah satu akitivitas fisik yang dapat meningkatkan sirkulasi darah. Tujuan dari penelitian ini adalah untuk menganalisis pengaruh therapeutic exercise walking terhadap sirkulasi darah perifer pada pasien diabetes melitus tipe 2. Desain penelitian ini adalah randomized control group pretest-posttest design. Besar sampel yang digunakan adalah 15 responden pada kelompok kontrol dan 15 responden pada kelompok perlakuan. Data dianalisis menggunakan uji t dependen dan uji $t$ independen dengan tingkat kesalahan 0,05. Hasil penelitian menunjukkan peningkatan $\mathrm{ABI}$ yang signifikan setelah dilakukan therapeutic exercise walking pada kelompok perlakuan $(\mathrm{p}=0,001)$. Disisi lain ada penurunan nilai $\mathrm{ABI}$ yang signifikan antara pretest dan posttest pada kelompok kontrol $(p=0,010)$. Uji $t$ independen menunjukkan terdapat perbedaan nilai $A B I$ yang signifikan antara kelompok perlakuan dan kelompok kontrol $(p=0,000)$. Jadi, dapat disimpulkan terdapat pengaruh therapeutic exercise walking terhadap sirkulasi darah perifer pada pasien diabetes melitus tipe 2. Perawat sebaiknya menerapkan therapeutic exercise walking untuk meningkatkan sirkulasi darah perifer pada pasien diabetes melitus tipe 2 .
\end{abstract}

Kata kunci: diabetes melitus tipe 2, therapeutic exercise walking, ankle brachial index 


\section{Pendahuluan}

Diabetes melitus (DM) adalah salah satu penyakit degeneratif yang memiliki angka morbiditas dan mortalitas terbanyak di Indonesia [1]. DM tipe 2 adalah salah satu jenis penyakit yang bersifat kronis dengan karakteristik adanya kenaikan kadar glukosa darah (KGD) atau hiperglikemia karena penurunan insulin atau resistensi insulin [2]. Jumlah penyandang DM di dunia pada tahun 2014 adalah sebanyak 387 juta dengan prevalensi 8,3\% dan diperkirakan akan meningkat menjadi 592 juta pada tahun 2035. Angka kejadian DM di Indonesia menempati urutan ke dua setelah Cina yaitu sebanyak 9,116 juta dengan prevalensi sebesar 5,81\% [3]. Provinsi Jawa Timur berada pada urutan ke-9 dengan prevalensi DM diatas prevalensi nasional yaitu sebesar 2,5\% [1]. Data kunjungan puskesmas di Jawa Timur pada tahun 2010 menunjukkan DM merupakan penyakit tidak menular terbanyak kedua dengan presentase kunjungan 3,61\% [4].

Data Dinas Kesehatan Kabupaten Jember pada tahun 2014 menunjukkan bahwa jumlah kunjungan pasien DM tipe 2 sebanyak 11.358 kunjungan $[5,6]$. Kunjungan pasien DM tipe 2 terbanyak adalah di puskesmas Patrang yaitu

1.078 kunjungan [7]. Berdasarkan data puskesmas Patrang pada bulan April sampai September 2015 dan bulan Januari sampai Februari 2016 terdapat 387 kunjungan dengan jumlah pasien DM tipe 2 sebanyak 198 orang. Jumlah pasien terdaftar terbanyak adalah di Kelurahan Gebang yaitu 54 pasien.

Pasien DM tipe 2 beresiko mengalami komplikasi yang bersifat kronis melalui adanya kerusakan pada sistem vaskular berupa mikroangiopati dan makroangipati [2]. Komplikasi yang paling sering terjadi yaitu adanya penyakit pembuluh darah perifer [8]. Menurut data komplikasi DM di RSCM Jakarta pada tahun 2011, komplikasi PAD (peripheral arterial disease) menempati urutan ke empat dengan presentase 10,8\% [1].

Kadar glukosa darah yang tinggi (hiperglikemia) yang berlangsung secara kronis pada pasien DM tipe 2 menyebabkan peningkatan reactive oxygen species (ROS) dan menurunnya NO yang berdampak pada rusaknya sel endotel pembuluh darah serta terganggunya elastisitas pembuluh darah sehingga plauqe akan mudah menempel [10]. Hal tersebut memberikan dampak pada sirkulasi sistemik yaitu penurunan sirkulasi darah perifer. Penurunan sirkulasi darah perifer pada pasien
DM tipe 2 terutama terjadi di kaki. Penurunan sirkulasi darah perifer dapat menyebabkan resiko komplikasi trauma kaki pada pasien DM tipe 2 meningkat [8].

Penilaian gangguan sirkulasi darah perifer dapat dilakukan dengan nilai Ankle Brachial Index (ABI) [11]. Nilai $A B I$ diperoleh dari pembagian tekanan sistolik kaki dibagi dengan tekanan sistolik brakhialis [4]. Nilai $A B I$ yang rendah pada pasien DM berhubungan dengan risiko adanya gangguan sirkulasi darah perifer yang lebih tinggi [12]. Berdasarkan hasil studi pendahuluan terhadap 10 pasien DM tipe 2 di Kelurahan Gebang didapatkan rata-rata nilai $\mathrm{ABI}$ sebesar 0,79 . Sebanyak tujuh orang dari sepuluh pasien $\mathrm{DM}$ tipe 2 mempunyai nilai $\mathrm{ABI}$ dalam kategori adanya oklusi minimal.

Salah satu penatalaksanaan DM yang bisa dilakukan untuk meningkatkan sirkulasi darah adalah dengan melakukan latihan jasmani [13]. Therapeutic exercise wakling adalah salah satu latihan fisik berupa tindakan jalan biasa dengan gerakan tangan yang diayun sesuai irama jalan sehingga tindakan ini akan melibatkan semua gerakan tubuh. Therapeutic exercise walking dapat berfungsi untuk melancarkan sirkulasi darah karena latihan ini menyebabkan pembuluh darah banyak yang terbuka dan meningkatkan kapasitas oksidatif otot [14]. Peningkatan aktifitas fisik dapat menurunkan komplikasi mikrovaskular maupun makrovaskular [15]. Latihan fisik akan memicu penggunaan glukosa darah dan asam lemak bebas dalam otot sehingga kadar glukosa darah menjadi menurun dan dapat terkontrol [22]. Berdasarkan permasalahan diatas maka peneliti ingin menganalisis pengaruh therapeutic exercise walking terhadap sirkulasi darah perifer pada pasien DM tipe 2.

\section{Metode Penelitian}

Metode penelitian ini adalah quasi experimental dengan desain penelitian pretestpostest with control group design. Populasi penelitian ini adalah pasien DM tipe 2 di Kelurahan Gebang sebanyak 54. Kriteria inklusi penelitian adalah didiagnosis DM tipe 2, usia 4065 tahun, lama $D M \geq 5$ tahun, menggunakan obat hipoglikemi oral (OHO), kadar gula darah sewaktu tidak lebih dari $300 \mathrm{mg} / \mathrm{dL}$ dan tidak kurang dari $70 \mathrm{mg} / \mathrm{dL}$, tekanan darah sistolik 90$180 \mathrm{mmHg}$, respiration rate $12-20 \mathrm{x} /$ menit, frekuensi nadi $60-100 x / m e n i t$, bertempat tinggal di Kelurahan Gebang Kecamatan Patrang, dan bersedia menjadi responden penelitian. Kriteria eksklusi responden adalah terdapat gangguan 
pada bagian ektermitas bawah seperti adanya ulkus diabetik, gangren, tidak mampu berjalan, dan adanya fraktur pada kaki, memiliki keterbatasan fisik seperti dalam melihat (buta), tidak bisa mendengarkan (tuli), terdapat penyakit penyerta seperti gagal ginjal kronik dan gagal jantung, dan tidak bisa berpartisipasi dalam keseluruhan kegiatan latihan atau mengundurkan diri menjadi responden penelitian. Dari 54 pasien terdapat 36 pasien

yang memenuhi kriteria untuk dijadikan sampel

penelitian. Teknik simple random sampling dilakukan terhadap 36 pasien tersebut untuk menentukan 30 sampel penelitian dan untuk membagi 15 responden sebagai kelompok perlakuan dan 15 responden sebagai kelompok

kontrol.

Penelitian ini dilaksanakan di Kelurahan

Gebang Kecamatan Patrang Kabupaten Jember. Waktu Penelitian dilakukan pada bulan September 2015 sampai dengan Mei 2016. Pengumpulan data dilakukan pada bulan Maret sampai April 2016. Latihan dilakukan 3x dalam seminggu dengan total $12 x$ dalam satu bulan, dan 40 menit setiap sesi. Teknik pengumpulan data dalam penelitian ini menggunakan nilai Ankle Brachial Index ( $\mathrm{ABI}$ ) yang diukur dengan sphygmomanometer dengan metode palpasi. Data dianalisis dengan menggunakan uji $t$ dependent dan uji t independent dengan derajat kepercayaan $95 \%(\alpha=0,05)$. Etika penelitian pada penelitian ini adalah Informed consent dan anonimity untuk menjaga kerahasiaan responden.

\section{Hasil Penelitian}

\section{Karakteristik Responden}

Tabel 1. Distribusi Karakteristik Responden Berdasarkan Usia dan Lama Sakit DM

\begin{tabular}{|c|c|c|c|}
\hline Variabel & Mean & SD & $\begin{array}{l}\text { Minimum- } \\
\text { Maksimum }\end{array}$ \\
\hline \multicolumn{4}{|l|}{ Usia (tahun) } \\
\hline $\begin{array}{l}\text { perlakuan }(n=15) \\
\text { Kontrol }(n=15)\end{array}$ & $\begin{array}{l}50,80 \\
51,07\end{array}$ & $\begin{array}{l}6,53 \\
5,14\end{array}$ & $\begin{array}{l}41-62 \\
43-60\end{array}$ \\
\hline Total $(n=30)$ & 50,93 & 5,78 & $41-62$ \\
\hline \multicolumn{4}{|l|}{ Lama DM (bulan) } \\
\hline perlakuan $(n=15)$ & 96,33 & 32,9 & $74-208$ \\
\hline Kontrol $(n=15)$ & 87,40 & 13,7 & $65-110$ \\
\hline Total $(n=30)$ & 91,87 & 25,2 & $65-208$ \\
\hline
\end{tabular}

Tabel 1 menunjukkan rata-rata usia responden pada penelitian ini adalah 50,93 tahun dengan SD 5,78. Rata-rata usia responden e-Jurnal Pustaka Kesehatan, vol.8 (no.1), January, 2020 adalah 91,87 bulan dengan SD 25,2. Rata-rata lama sakit DM pada kelompok perlakuan adalah selama 96,33 bulan dan pada kelompok kontrol adalah selama 87,40 bulan.

Tabel 2. Distribusi karakteristik responden berdasarkan Jenis Kelamin, Riwayat Pendidikan, Pekerjaan, Status Merokok, Dan Konsumsi OHO di Kelurahan Gebang Kecamatan Patrang Kabupaten Jember

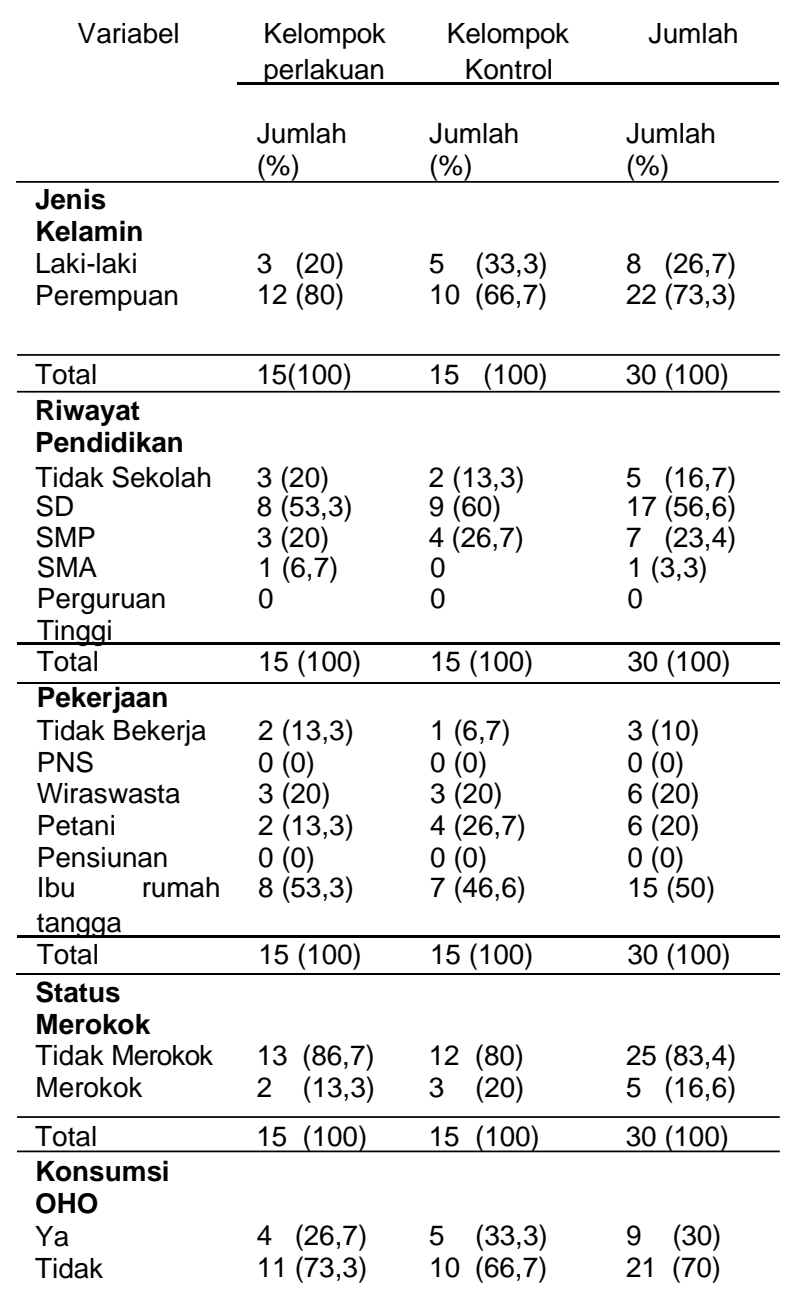

kelompok perlakuan 50,80 tahun dan kelompok kontrol 51,07 tahun. Rata-rata mengalami DM pada respnden penelitian ini 
Dewi, et al, Pengaruh Therapeutic Exercise Walking terhadap Sirkulasi Darah Perifer....

Total $15(100) \quad 15(100) \quad 30(100)$

Berdasarkan tabel 2 sebagian besar responden adalah perempuan 22 orang (73,3\%). Responden perempuan di kelompok perlakuan sebanyak $12(80 \%)$ dan 10 orang pada kelompok kontrol. Lebih dari separuh responden memiliki riwayat pendidikan sekolah dasar (SD) yaitu 17 orang (56,6\%). Responden pendidikan SD sebanyak 8 orang $(53,3 \%)$ pada kelompok perlakuan dan 9 orang $(60 \%)$ pada kelompok kontrol. Sebanyak $50 \%$ responden adalah ibu rumah tangga. Responden ibu rumah tangga sebanyak 8 orang $(53,3 \%)$ pada kelompok perlakuan dan 7 orang $(46,6 \%)$ pada kelompok kontrol. Sebagian besar responden tidak mengkonsumsi $\mathrm{OHO}$ yaitu sebanyak 22 
Dewi, et al, Pengaruh Therapeutic Exercise Walking terhadap Sirkulasi Darah Perifer....

orang (70\%). Responden tidak mengkonsumsi OHO sebanyak 11 orang $(73,3 \%)$ pada kelompok perlakuan dan 10 orang $(66,7 \%)$ pada kelompok kontrol.

\section{Nilai ABI pada Kelompok Perlakuan dan}

\section{Kelompok Kontrol}

Tabel 3. Perbedaan Nilai ABI Pretest dan Postest pada Kelompok Perlakuan dan Kontrol

\begin{tabular}{|c|c|c|c|}
\hline \multirow{2}{*}{$\begin{array}{c}\text { Variabel nilai } \\
\text { ABI }\end{array}$} & \multicolumn{2}{|c|}{ Mean } & \multirow{2}{*}{$\begin{array}{c}\text { Mean } \\
\text { Difference }\end{array}$} \\
\hline & Pretest & Postest & \\
\hline $\begin{array}{l}\text { Kelompok } \\
\text { Perlakuan }\end{array}$ & 0,806 & 0,901 & 0,095 \\
\hline $\begin{array}{l}\text { Kelompok } \\
\text { Kontrol }\end{array}$ & 0,800 & 0,730 & $-0,070$ \\
\hline
\end{tabular}

Tabel 3 menunjukkan bahwa terjadi peningkatan rata-rata nilai $\mathrm{ABI}$ pada kelompok perlakuan sebesar 0,095 yaitu dari 0,806 menjadi 0,901. Pada kelompok kontrol terjadi penurunan ratarata nilai $A B I$ sebesar 0,070 yaitu dari nilai 0,800 menjadi 0,730 .

Tabel 4. Kategori Nilai Ankle Brachial Index (ABI) Pretest dan Postest Dilakukan Therapeutic Exercise Walking pada Kelompok perlakuan dan kontrol

\begin{tabular}{|c|c|c|c|c|}
\hline \multirow{2}{*}{$\begin{array}{c}\text { Kategori } \\
\text { Oklusi }\end{array}$} & \multicolumn{2}{|c|}{ Perlakuan } & \multicolumn{2}{|l|}{ Kontrol } \\
\hline & Pretest & Postest & Pretest & Postest \\
\hline \multirow[t]{2}{*}{$\mathrm{ABI}$} & Jumlah & Jumlah & Jumlah & Jumlah \\
\hline & $(\%)$ & $(\%)$ & $(\%)$ & $(\%)$ \\
\hline Parah & $0(0)$ & $0(0)$ & $0(0)$ & $0(0)$ \\
\hline Sedang & $2(13,3)$ & $2(13,3)$ & $2(13,3)$ & $3(20)$ \\
\hline Minimal & $9(60)$ & $6(40)$ & $8(53,3)$ & $11(73,3)$ \\
\hline Normal & $4(26,7)$ & $7(46,7)$ & $5(33,3)$ & $1(6,7)$ \\
\hline Total & $15(100)$ & $15(100)$ & $15(100)$ & $15(100)$ \\
\hline
\end{tabular}

Tabel 4 menunjukkan nilai $A B I$ pada kelompok perlakuan sebelum dilakukan Therapeutic Exercise Walking adalah sebanyak 11 responden (73\%) masuk kedalam kategori adanya oklusi (9 responden oklusi minimal dan 2 responden oklusi sedang). Setelah dilakukan Therapeutic Exercise Walking, nilai $\mathrm{ABI}$ pada responden mengalami peningkatan sehingga terdapat 8 responden (53\%) yang masuk kedalam kategori adanya oklusi (6 orang oklusi minimal dan 2 orang oklusi sedang). Nilai $A B I$ pada kelompok kontrol terdapat 8 responden (53,3\%) dalam kategori oklusi minimal dan 5
Tabel 5. Hasil Uji t Dependen Nilai Ankle Brachial Index (ABI) antara Kelompok perlakuan dan Kelompok Kontrol

\begin{tabular}{llccc}
\hline Kelompok & Nilai ABI & Mean & $\mathrm{t}$ & $\mathrm{p}$ \\
\hline \multirow{4}{*}{ Perlakuan } & & & & \\
\multirow{3}{*}{ Kontrol } & Pretest & 0,806 & & \\
& Posttest & $0,8,801$ & -158 & 0,001 \\
& Pretest & & 2,987 & 0,010 \\
& Posttest & 0,730 & & \\
\hline
\end{tabular}

Hasil analisis tabel 5 diatas menunjukkan

hasil dari uji t dependen pada kelompok

perlakuan dan kelompok kontrol. Kelompok perlakuan memiliki nilai t hitung $-4,158$, $t$ tabel

3,787 dan $p=0,001$ yang berarti thitung $>t$ tabel dan $p<\alpha(0,05)$, artinya bahwa terdapat perbedaan nilai $A B I$ yang signifikan antara

sebelum dan sesudah intervensi. Nilai t negatif pada kelompok perlakuan menunjukkan terjadi peningkatan nilai $\mathrm{ABI}$ setelah dilakukan intervensi. Hasil uji t dependent pada kelompok kontrol didapatkan nilai t hitung 2,987, nilai t tabel 1,345 dan $p=0,010$ yang berarti t hitung $>t$ tabel dan $p<\alpha(0,05)$, artinya bahwa kelompok kontrol terdapat perbedaan yang signifikan pada nilai $A B I$. Nilai $t$ positif pada kelompok kontrol menunjukkan terjadi penurunan nilai $\mathrm{ABI}$ pada posttest.

Tabel 6. Hasil Uji t Independen Nilai Ankle Brachial Index (ABI) antara kelompok

\begin{tabular}{|c|c|c|c|c|}
\hline Vari & abel & $\begin{array}{c}\text { Mean } \\
\text { Difference }\end{array}$ & $\mathrm{t}$ & $P$ \\
\hline \multirow{2}{*}{$\begin{array}{l}\mathrm{ABI} \\
\text { perlakuan } \\
\mathrm{ABI}\end{array}$} & Kelompok & 0,095 & \multirow[b]{2}{*}{5,065} & \multirow[b]{2}{*}{0,000} \\
\hline & Kelompok & $-0,070$ & & \\
\hline
\end{tabular}

responden $(33,3 \%)$ masuk dalam kategori normal pada awal pemeriksaan. Kelompok kontrol dilakukan pemeriksaan satu bulan kemudian, data menunjukkan jumlah responden dalam kategori oklusi minimal bertambah menjadi 11 responden $(73,3 \%)$ dan hanya 1 responden $(6,7 \%)$ dalam kategori normal. 
Tabel 6 diatas menunjukkan hasil dari uji t-independen pada variabel $\mathrm{ABI}$ kelompok perlakuan dan kelompok kontrol, yaitu nilai $t$ sebesar 5,065 dan nilai $p 0,000$ yang berarti $p$ $<\alpha(0,05)$. Hasil tersebut menunjukkan bahwa terdapat perbedaan nilai $\mathrm{ABI}$ yang signifikan antara kelompok perlakuan dan kelompok kontrol. Nilai positif pada t menunjukkan nilai $\mathrm{ABI}$ pada kelompok perlakuan lebih tinggi daripada nilai $A B I$ kelompok kontrol.

\section{Pembahasan}

\section{Karakteristik Responden}

Hasil penelitian menunjukkan bahwa rata- rata usia responden pada penelitian ini adalah 50,93 tahun. Bertambahnya usia seseorang menyebabkan terjadinya peningkatan resiko diabetes melitus. Kenaikan kadar glukosa darah (KGD) sering dikaitkan dengan pertambahan 
usia, sehingga semakin meningkatnya usia maka gangguan toleransi glukosa dan prevalensi DM akan semakin tinggi. Pertambahan usia seseorang diikuti dengan perubahan fungsi endokrin pankreas sehingga produksi insulin menurun [2].

Rata-rata lama DM responden penelitian adalah 91,87 bulan. DM merupakan penyakit metabolik yang berlangsung secara terus menerus yang tidak bisa disembuhkan, sehingga hanya bisa kendalikan [11]. Seseorang yang mengalami sakit DM tipe 2 lebih dari 5 tahun setelah didiagnosa maka resiko terjadinya komplikasi makrovaskuler akan semakin meningkat [23].

Responden pada penelitian ini didominasi oleh perempuan yaitu sebanyak 22 orang (73,3\%). Hal tersebut berhubungan dengan presentase timbunan lemak pada tubuh seorang perempuan lebih besar jika dibandingkan pada tubuh laki-laki. Timbunan lemak yang besar akan memberikan pengaruh terhadap penurunan sensifitas insulin [21].

Riwayat pendidikan terbanyak responden adalah sekolah dasar sebanyak $56,6 \%$. Pendidikan seseorang menjadi aspek status sosial yang berhubungan dengan status kesehatan. Terdapat hubungan antara tingkat pendidikan dengan kejadian DM, dimana orang dengan tingkat pendidikan yang rendah memiliki resiko 1,27 kali mengalami DM daripada orang yang berpendidikan tinggi [24].

Pekerjaan terbanyak responden pada penelitian ini adalah ibu rumah tangga sebanyak 15 orang (50\%). Hubungan pekerjaan dengan DM seringkali dikaitkan dengan tingkat aktivitas fisik yang dilakukan. Seseorang yang kurang melakukan aktivitas fisik beresiko mengalami DM karena penyerapan gula oleh jaringan tubuh saat istirahat, sedangkan pada otot yang aktif tidak disertai kenaikan insulin walaupun kebutuhan gula darah meningkat [25].

Status merokok responden adalah hanya 5 orang $(16,6 \%)$ yang merupakan perokok aktif. Seseorang yang telah didiagnosis DM, seharusnya harus bisa berhenti merokok. Zat nikotin yang ada dalam rokok dapat berpengaruh pada pembuluh darah dengan penyempitan pembuluh darah. Penyempitan pembuluh darah tersebut akan mengganggu peredaran darah termasuk ke otak, jantung, dan kaki sehingga akan memperburuk kondisi sirkulasi darah perifer [8].

Perbandingan jumlah responden yang mengkonsumsi $\mathrm{OHO}$ adalah $70 \%$ tidak mengkonsumsi $\mathrm{OHO}$. Terapi farmakologis adalah salah satu pilar penatalaksanaan DM. Penatalaksanaan DM dilakukan untuk mengontrol KGD pasien. OHO bekerja dengan beberapa mekanisme pada pasien DM, yaitu melalui peningkatan sekresi hormon insulin, memberikan pengaruh pada kerja hormon insulin tingkat seluler, reseptor insulin, dan produksi glukosa hati yang diturunkan [26].

\section{Nilai ABI Sebelum dan Sesudah Therapeutic Exercise Walking pada Kelompok Perlakuan}

Rata-rata nilai $\mathrm{ABI}$ pada kelompok perlakuan setelah dilakukan therapeutic exercise walking mengalami peningkatan sebesar 0,095. Responden pada kelompok perlakuan mengikuti latihan therapeutic exercise walking sesuai dengan jadwal yang sudah disepakati. Salah satu penentu keberhasilan latihan jasmani adalah dosis yang cukup dikenal dengan konsep FIT (Frequency, Intensity, Time) [20]. Frekuensi menunjukkan banyaknya latihan dalam persatuan waktu dan untuk memberikan hasil peningkatan kebugaran fisik. Penelitian ini menggunakan frekuensi melakukan therapeutic exercise walking sebanyak 3 kali dalam seminggu. Intensitas merupakan gambaran kualitas yang menunjukkan berat atau ringannya suatu latihan yang dilakukan. Intensitas dihitung dengan menggunakan perhitungan target heart rate range (THRR), dimana pada penelitian ini menggunakan THRR 50 - 85\% detak jantung maksimal. Prinsip yang terakhir adalah time. Time adalah waktu atau durasi yang digunakan untuk satu kali latihan. Penelitian ini menggunakan durasi waktu 30 menit setiap kali pertemuan latihan. Jadi dalam satu minggu, masing-masing responden pada kelompok perlakuan melakukan therapeutic exercise walking dengan durasi 90 menit/minggu.

Durasi latihan akan meningkatkan penggunaan glukosa oleh tubuh, sehingga kadar glukosa darah turun. Semakin lama durasi maka glukosa dalam darah akan semakin banyak diambil oleh sel untuk menghasilkan energi [9]. Latihan fisik juga akan memicu penggunaan glukosa darah dan asam lemak bebas dalam otot sehingga kadar glukosa darah menjadi menurun dan dapat terkontrol [17]. Kadar glukosa darah yang terkontrol akan membantu meningkatkan NO yaitu dengan meningkatkan protein eNOS sehingga NO plasma meningkat [18]. Ketika NO meningkat maka peran dalam profilaksis aterosklerosis akan berjalan maksimal dan hasil akhirnya akan memperbaiki penyempitan akibat aterosklerosis dengan cara plauqe yang menempel di dinding 
pembuluh darah menipis, maka suplai darah oksigen pada jaringan akan meningkat [20].

Latihan fisik yang dilakukan dengan teratur dapat mengeluarkan hormon epinefrin dan norepinefrin yang berfungsi untuk meningkatkan kerja jantung untuk lebih efektiif dalam proses aliran darah. Seseorang yang melakukan latihan fisik akan menyebabkan otot akan bergerak lebih aktif [16]. Mekanisme pengambilan glukosa oleh otot yang aktif disebabkan beberapa hal yaitu insulin akan memacu pelepasan muscle activating factor (MAF) pada otot yang sedang bergerak, sehingga hal tersebut menyebabkan ambilan glukosa oleh otot menjadi meningkat dan pengambilan glukosa oleh otot yang tidak bergerak juga meningkat [20].

\section{Nilai Ankle Brachial Index (ABI) Sebelum dan Sesudah pada Kelompok Kontrol}

Rata-rata postest nilai $\mathrm{ABI}$ kelompok kontrol mengalami penurunan sebesar 0,07. Penelitian pada kelompok kontrol tidak dilakukan perlakuan therapeutic exercise walking, dan lebih dari separuh dari responden menyatakan jarang melakukan olahraga, hanya terkadang jalan di pagi hari tapi tidak teratur. Latihan jasmani pada pasien DM memiliki peran yang penting dalam penatalaksanaan DM. Kurangnya latihan jasmani pada orang DM akan menyebabkan jumlah energi yang dikonsumsi lebih banyak dibandingkan jumlah energi yang dikeluarkan. Hal ini akan menimbulkan keseimbangan energi yang positif yang disimpan pada jaringan adiposa. Dampak dari hal tersebut adalah resistensi insulin pada pasien DM akan semakin berkembang dan kadar glukosa darah tidak terkontrol [21].

Kadar glukosa darah yang tidak terkontrol dengan baik dan berlangsung secara terus menerus akan menyebabkan kerusakan pada pembuluh darah yang akan berakhir dengan terbentuknya aterosklerosis. Aterosklerosis adalah suatu respon inflamasi kronik pada dinding arteri yang diawali dengan injury pada endotel. Disfungsi endotel akan menyebabkan perlekatan monosit dan platelet ke endotel pembuluh darah, monosit akan mengalami emigrasi dari lumen ke lapisan intima. Sel-sel dari otot polos juga akan mengalami migrasi dari lapisan media ke intima sehingga makrofag mengalami aktivasi. Makrofag dan sel otot polos akan memakan lemak dan menimbulkan timbunan lemak pada intima. Proses tersebut akan menimbulkan plak, poliferasi sel otot polos serta penumpukkan extraselules matrix, kolagen dan extraseluler lipid. Terbentuknya aterosklerosis akan menyebabkan sirkulasi darah menjadi tidak lancar [22].

\section{Pengaruh Therapeutic Exercise Walking Terhadap Sirkulasi Darah Perifer.}

Hasil analisis tabel 6 menunjukkan hasil uji $t$ independen dimana didapatkan nilai $t=5,065$ dan nilai $p=0,000$, yang berarti $p<\alpha(0,05)$, artinya terdapat perbedaan nilai $\mathrm{ABI}$ yang signifikaan antara kelompok perlakuan dan kelompok kontrol. Nilai $\mathrm{ABI}$ pada kelompok perlakuan mengalami peningkatan dan nilai $A B I$ pada kelompok kontrol mengalami penurunan. Nilai $\mathrm{ABI}$ dipengaruhi banyak faktor salah satunya adalah latihan jasmani. Therapeutic exercise walking merupakan salah satu jenis latihan jasmani yang direkomendasikan untuk penyandang DM. Latihan jasmani merupakan tindakan preventif untuk mengurangi atau mengimbangi efek dari diabetes melitus. Latihan yang dilakukan oleh penyandang DM bertujuan untuk memperbaiki sensitivitas insulin, membakar lemak berlebih di dalam tubuh, mengontrol berat badan, meningkatkan kekuatan otot, menurunkan tekanan darah, membantu melindungi penyakit jantung dan pembuluh darah. Latihan jasmani yang teratur akan efektif dapat memperlambat jalannya diabetes dan mencegah gangguan pembuluh darah mikro seperti nefropati, neuropati perifer, dan pembuluh darah makro seperti jantung koroner, stroke, dan penyakit pembuluh darah arteri [21].

Latihan akan meningkatkan transportasi glukosa melalui kontraksi otot. Kontraksi otot akan menimbulkan peningkatan kebutuhan glukosa di dalam otot yang lebih lanjut melalui mekanisme kerja insulin, yaitu dengan memberi sinyal terhadap GLUT-4 berpindah ke permukaan sel untuk membawa glukosa masuk. Mekanisme ini juga bisa terjadi tanpa kerja insulin yaitu dengan mekanisme $\mathrm{Ca}++$ selama kontraksi otot terjadi. Mekanisme ini akan mengeluarkan protein 5'AMP kinase yang memiliki fungsi mengaktifkan perpindahan GLUT-4 ke permukaan sel. Selain itu, latihan juga meningkatkan jumlah mitokondria yang dipengaruhi oleh NO, sehingga menyebabkan lemak teroksidasi di permukaan sel meningkat dan sensitivitas reseptor insulin juga meningkat [9].

Masalah resistensi insulin pada pasien DM berhubungan dengan tingginya konsentrasi trigliserida yang tinggi. Latihan jasmani menjadi metode yang efektif dilakukan untuk 
meningkatkan volume mitokondria dan enzim lipoprotein lipase yang akan bertanggung jawab untuk meningkatkan kemampuan katabolisme lemak selama melakukan olahraga. Latihan jasmani aerobik menyebabkan peningkatan oksidasi lemak dan penurunan trigliserida pada pasien diabetes melitus sehingga akan terjadi perubahan positif dalam profil lemak pasien DM [21]. Hal ini juga berdampak pada penurunan kolesterol LDL dan meningkatkan HDL, sehingga sensitivitas reseptor insulin akan meningkat [27].

Latihan fisik akan menyebabkan kontraksi otot pada rangka yang akan menekan pembuluh darah di seluruh tubuh. Hal ini akan berpengaruh pada sistem kardioakselerasi dimana sistem ini akan mempengaruhi pengeluaran hormon epinefrin dan noreepinefrin yang bisa memperlancar perfusi aliran darah. Ketika melakukan olahraga secara rutin dan berkesinambungan akan mempengaruhi kerja korteks adrenal, dimana akan menstimulasi pengeluaran hormon epinefrin dan noreepinefrin yang akan berfungsi untuk meningkatkan kerja jantung lebih efektif dalam proses aliran darah. Reseptor $\beta 1$ pada jantung yang berfungsi kardioakselerasi dalam memompa darah ke seluruh tubuh akan dirangsang epinefrin pada saat dilakukan latihan jasmani. Selain itu, juga akan berpengaruh terhadap meningkatnya isi volume sekuncup melebihi 35L/menit, jumlah ini setara dengan peningkatan konsumsi oksigen, proses ini akan menyebabkan aliran balik vena. Efek kardioakselerasi ini akan menyebabkan aliran darah banyak pada otot untuk mendukung metabolisme pada saat melakukan aktivitas dan sirkulasi darah akan lancar [16].

Berdasarkan penjelasan diatas, dapat disimpulkan bahwa pengaruh therapeutic exercise walking terhadap nilai $A B I$ terjadi melalui proses kontraksi otot yang terjadi secara berlanjut yang menjadikan glukosa terpakai sebagai energy sehingga KGD terkontrol. Efek kardioakselerasi juga terjadi sehingga aliran darah menjadi lancar serta nilai $\mathrm{ABI}$ meningkat. Selain itu, oksidasi lemak meningkat sehingga sensitivitas reseptor insulin meningkat.

\section{Simpulan dan Saran}

Terdapat pengaruh therapeutic exercise walking terhadap sirkulasi darah perifer pasien DM tipe 2. Therapeutic Exercise Walking dapat meningkatkan nilai $\mathrm{ABI}$ pasien DM Tipe 2. Perawat dapat memberikan pendidikan kesehatan tentang therapeutic exercise walking dapat meningkatkan sirkulasi darah perifer pada pasien DM tipe 2. Bagi peneliti selanjutnya diharapkan untuk menggunakan sampel yang lebih besar, menggunakan alat doppler, dan mengontrol variabel pengganggu seperti merokok, konsumsi $\mathrm{OHO}$, dan hipertensi.

\section{Daftar Pustaka}

[1] Indonesia. Penyakit tidak menular (PTM) penyebab kematian terbanyak di Indonesia. Jakarta: Kementrian Kesehatan Republik Indonesia. [serial online] 2014. [diambil tanggal 21 Oktober 2015] dari: http://www.depkes.go.id/article/view/1637/p enyakit-tidak-menular-ptm-penyebabkematian-terbanyak-diindonesia.html\#sthash.svKse1Xc.dpuf

[2] Suzanne CS, \& Brenda GB. Buku ajar keperawatan medikal bedah Vol.2. Ed.10. Jakarta: EGC; 2008.

[3] International Diabetes Federation. IDF diabetes atlas sixth edition. [serial online]. 2014. [diambil tanggal 5 april 2015] dari: http://www.idf.org/diabetesatlas

[4] Marlene SG, Joen Gagnon, York Hsiang. Ankle brachial index for assessment of peripheral arterial disease. [serial online]. 2009. [diambil tanggal 19 April 2015] dari: http://www.whs-egypt.net/pdf/MeasureB.pdf 2009.

[5] Jawa Timur. Profil kesehatan provinsi Jawa Timur 2010. Surabaya: Dinas Kesehatan Jawa Timur; 2010.

[6] Jawa Timur. Laporan kunjungan (LBI) Kabupaten Jember Tahun 2014. Jember: Dinas Kesehatan Kabupaten Jember; 2014

[7] Jawa Timur. Laporan kunjungan (LBI) Kabupaten Jember Tahun 2015. Jember: Dinas Kesehatan Kabupaten Jember; 2015

[8] Hans T. Segala sesuatu yang harus anda ketahui tentang diabetes: panduan lengkap mengenal dan mengatasi diabetes dengan cepat dan mudah. Jakarta: PT. Gramedia Pustaka Utama; 2007

[9] Korina W. Efek latihan dengan ergocycle terhadap kadar glukosa darah pada penderita diabetes melitus tipe 2 anggota klub persadia. 2013. [diambil tanggal 22 April 2016] dari. eprints.uny.ac.id/14121/1/skripsi.pdf

[10] Jeffrey JS \& Chaikof EL. The pathogenesis of diabeteic atherosclerosis [serial online]. 2012 [diambil tanggal 22 Oktober 2015] dari: 
Dewi, et al, Pengaruh Therapeutic Exercise Walking terhadap Sirkulasi Darah Perifer....

http://www.springer.com/cda/content/docu ment/cda downloaddocument/9781627031 578-c1.pdf?SGWID=0

[11] American Diabetes Association. Standards of medical care in diabetes. 2013. [diambil tanggal 20 april 2015] dari: care.diabetesjournals.org/content/36/Suppl ement 1/S11.full.pdf

[12] Maria S. Hubungan antara penyakit arteri perifer dengan faktor risiko kardiovaskular pada pasien dm tipe 2. 2013. [diambil tanggal November 2015] dari: ejournal.unsrat.ac.id/index.php/eclinic/articl e/download/1179/955

[13] Sylvia AP \& Lorraine MW. Patofisiologi: konsep klinis proses-proses penyakit, Edisi 6, Vol 2, Alih bahasa, Brahm U.Pendit. Jakarta: EGC; 2006.

[14] Kuntaraf K. Olahraga sumber kesehatan. Jakarta: Indonesia Pubhlising House; 1996.

[15] Ning $H$. Menumpas diabetes mellitus bersama mahkota dewa. Jakarta: PT Agro Media Pustaka; 2004

[16] Arthur CG \& John EH. Buku ajar fisiologi kedokteran. Jakarta: EGC; 2007.

[17] Dawn BM, Allan DM, Colleen MS. Biokimia kedokteran dasar: sebuah pendekatan klinis. Jakarta: EGC; 2000.

[18] Ghozi N. Hubungan aktivitas fisik dengan kadar nitrit oxide (no) plasma pada masyarakat di kota padang. 2014. [diambil tanggal 29 Maret 2015] dari: jurnal.fk.unad.ac.id/index.php/jka/article/vie w/77

[19] Misnadiarly. Diabetes mellitus: gangren, ulcer, infeksi. Mengenal gejala, menanggulangi, dan mencegah komplikasi. Jakarta: Pustaka Populer Obor; 2006.

[20] Puji I. Pengaruh latihan fisik:senam aerobik terhadap penurunan kadar gula darah pada penderita $\mathrm{dm}$ tipe 2 di wilayah puskesmas Bukateja Purbalingga [Serial online]. 2010. [diambil tanggal 21 September 2015] dari: http://www.ejournal.undip.ac.id/index.php/m edianers/article/download/717/586

[21] Amir. The effect of 4-weeks aerobic training according with the usage of anethum graveolens on blood sugar and lipoproteins profile of diabetic women. [serial online]. 2012 [diambil tanggal 17 September 2015] dari: www.scholarsresearchlibrary.com

[22] Fitriani L. Atherosclerosis. 2007. [diambil tanggal 20 April 2016] dari: repository.usu.ac.id/bitstream/123456789/2 060/1/09E01458.pdf

[23] Widyawati I. Pengaruh latihan rentang gerak sendi bawah secara aktif terhadap tanda dan gejala neuropati diabetikum pada pasien $\mathrm{dm}$ tipe 2 Di Persadia Unit RSU dr.Soetomo Surabaya. 2010. [diambil pada tanggal 14 April 2016] dari: lib.ui.ac.id/file?file=digital /137247-T\%20lka \%20Yuni\%20Widyawati.pdf

[24] Dedi I. Prevalensi dan faktor risiko kejadian diabetes melitus tipe 2 di daerah urban indonesia (analisa data sekunder riskesdas 2007). 2010. [diambil tanggal 14 April 2016] dari: http://lib.ui.ac.id/file? file=digital/20267101-T\%2028492Prevalensi\%20dan\%20faktor-full \%20text.pdf

[25] Ilyas E. Olahraga bagi diabetisi dalam: Soegondo,. S., Soewondo., Subekti, I., Editor, penatalaksanaan diabetes melitus terpadu bagi dokter maupun edukator diabetes. 2011. [diambil pada tanggal 15 April 2016] dari: NASKAH PUBLIKASI.pdf

[26] Suzanna N. diabetes mellitus tipe 2 dan tatalaksana terkini. 2014. [diambil tanggal 21 September 2015] dari: LEADING ARTICLE Diabetes Mellitus Ti pe 2 dan tata laksana terkini.pdf

[27] Ronald JS. Physical activity / exercise and type 2 diabetes. 2006. [diambil tanggal 11 September 2015] dari: diabetesjournals.org/content/29/6/1433.full. pdf 